\title{
Assessment of Myocardial Perfusion by Positron Emission Tomography
}

\author{
Markus Schwaiger, MD and Otto Muzik, PhD
}

\begin{abstract}
Positron emission tomography (PET) represents an advanced Imaging technology for the noninvasive evaluation of regional myocardial blood flow. Several blood flow tracers are avallable, includIng cyclotron-produced radlopharmaceuticals such as $\left[{ }^{13} \mathrm{O}\right] \mathrm{H}_{2} \mathrm{O}$ and $\left[{ }^{13} \mathrm{~N}^{-N_{3}}\right.$ and generator-produced rubidlum-82 ([ $\left.\left.{ }^{22} \mathrm{Rb}\right]-\right)$ and copper-62 ([ $\left.\left.{ }^{\mathrm{er}} \mathrm{Cu}\right]-\right)$ pyruvaldehyde-bis-( $N-4$-methylthiosemicarbazone) (PTSM). ${ }^{82} \mathrm{Rb}$ and $\left[{ }^{13} \mathrm{~N}_{\mathrm{NH}}\right.$ are the most commonly employed tracers for the qualitative evaluation of reglonal myocardial perfusion. Their use allows the accurate detection of coronary artery disease in combination with pharmacologic stress. Initial comparative studles with thallium$201\left({ }^{201} \mathrm{~T}\right)$ singlo-photon emisslon computed tomography (SPECT) have shown that PET has a higher dlagnostic accuracy.

Beyond Improved dlagnostic performance, the quantitative flow measurements provided by PET represent an important advance in nuclear cardiology. The radlopharmaceuticals $\left[{ }^{15} \mathrm{O}\right] \mathrm{H}_{2} \mathrm{O}$ and $\left[{ }^{13} \mathrm{~N} \mathrm{NH}_{3}\right.$ have been applied for the noninvasive determination of reglonal coronary reserve. Quantification of blood flow based on tracer klnetic modeling yields blood flow values in close agreement with determinations provided by invasive procedures. The neninvasive quantification of blood flow provides a useful research and clinical tool for the objective assessment of therapeutic interventions as well as pathophyslologic alterations of regional myocardlal blood flow in various cardlac diseases.
\end{abstract}

(Am J Cardlol 1991;67:35D-43D)

From the University of Michigan Medical Center, Department of Internal Medicine, Division of Nuclear Medicine, Ann Arbor, Michigan.

This work was done during the tenure of an established investigatorship from the American Heart Association (M. Schwaiger), and supported in part by the National Institutes of Health, Bethesda, MD (RO1 HL41047-01) and the Department of Energy, Washington, D.C. (DOE 89-035). Dr. Muzik is supported by the Austrian Erwin Schroedinger Foundation, J0473-MED.

Address for reprints: Markus Schwaiger, MD, University of Michigan Medical Center, 1500 E. Medical Center Drive, UH B1 G505, Box 0028, Ann Arbor, Michigan 48109-0028.
$\mathrm{P}$ ositron emission tomography (PET) technology has matured over recent years to become an established imaging modality for the noninvasive characterization of cardiac disease. Significant advances in scintigraphic data acquisition with multi-slice PET instrumentation allow three-dimensional determination of regional tissue tracer concentration. Furthermore, an abundance of radiopharmaceuticals labeled with carbon-11 $\left({ }^{11} \mathrm{C}\right)$, nitrogen-13 $\left({ }^{13} \mathrm{~N}\right)$, oxygen-15 $\left({ }^{15} \mathrm{O}\right)$, or fluorine-18 $\left({ }^{18} \mathrm{~F}\right)$ provide sophisticated delineation of specific tissue functions. The temporal definition of tissue tracer kinetics and subsequent analysis with mathematical models enable quantitative measurements of physiologic processes such as blood flow and metabolic rates.

Although coronary angiography is considered to be the "gold standard" for the characterization of coronary artery disease (CAD), data increasingly support the importance of noninvasively assessing the functional definition of the severity and extent of the disease process. ${ }^{1}$ Regional measurements such as absolute or relative coronary reserve have been shown to provide a sensitive marker for the functional significance of coronary artery stenoses. Such measurements represent functional correlates to the anatomic definition of vascular abnormalities occurring in $\mathrm{CAD}$. Although these measurements can be obtained invasively by several methods, at the present time PET represents the only noninvasive approach that accurately quantifies regional myocardial perfusion. ${ }^{2,3}$

This review addresses the clinical role of blood flow imaging with PET for the detection of CAD, using qualitative evaluation of regional tracer distribution. Additionally, current methods of quantification of regional myocardial blood flow under various physiologic conditions are compared.

\section{RADIOPHARMACEUTCALS}

Several blood flow tracers are available for the evaluation of myocardial perfusion using PET (Table I). Based on the mode of production, these radiopharmaceuticals are divided into two groups. Rubidium-82 ([ $\left.\left[{ }^{82} \mathrm{Rb}\right]-\right)$ and copper-62 $\left(\left[{ }^{62} \mathrm{Cu}\right]-\right)$ pyru- 


\begin{tabular}{|c|c|c|c|c|}
\hline & \multicolumn{4}{|c|}{ PET Myocardial Blood Flow Tracer } \\
\hline & EF & $\begin{array}{l}\text { Tissue } \\
\text { Half-life }\end{array}$ & $\begin{array}{l}\text { Physical } \\
\text { Half-life }\end{array}$ & $\begin{array}{l}\text { Positron } \\
\text { Energy MeV }\end{array}$ \\
\hline \multicolumn{5}{|l|}{ Generator-produced } \\
\hline Rubidium-82 & $\sim 65 \%$ & Long (hrs) & $1.3 \mathrm{~min}$ & 3.3 \\
\hline Copper-62 & $\sim 60 \%$ & Long (hrs) & $9.8 \mathrm{~min}$ & 2.9 \\
\hline \multicolumn{5}{|l|}{ Cyclotron-produced } \\
\hline$\left[{ }^{13} \mathrm{~N}\right] \mathrm{NH}_{3}$ & $\sim 90 \%$ & Long (hrs) & $10 \mathrm{~min}$ & 1.2 \\
\hline$\left[{ }^{15} \mathrm{O}_{\mathrm{O}} \mathrm{H}_{2} \mathrm{O}\right.$ & $\sim 100 \%$ & Short (sec) & $2 \mathrm{~min}$ & 1.72 \\
\hline${ }^{11} \mathrm{C}$ microspheres & $\sim 100 \%$ & Long (hrs) & $20 \mathrm{~min}$ & 0.96 \\
\hline
\end{tabular}

valdehyde-bis-( $N$-4-methylthiosemicarbazone) (PTSM) are generator-produced radiopharmaceuticals; $\left[{ }^{13} \mathrm{~N}\right] \mathrm{NH}_{3},\left[{ }^{15} \mathrm{O}\right] \mathrm{H}_{2} \mathrm{O}$, and ${ }^{11} \mathrm{C}$-labeled compounds require an on-site cyclotron for their production.

Cenerator-produced flow tracers: The strontium-82 $\left({ }^{82} \mathrm{Sr}\right) /{ }^{82} \mathrm{Rb}$ generator-produced flow tracer is commercially available. The radiopharmaceutical ${ }^{82} \mathrm{Rb}$, recently approved by the U.S. Food and Drug Administration for the evaluation of myocardial blood flow, ${ }^{4}$ is currently the most practical tracer available for PET imaging. The ${ }^{82} \mathrm{Sr} /{ }^{82} \mathrm{Rb}$ generator is being used in combination with a dedicated infusion system, which permits safe and reproducible administration of ${ }^{82} \mathrm{Rb}$ with minimal radiation exposure to the technical staff (Figure 1). The short physical half-life of ${ }^{82} \mathrm{Rb}$ (76 seconds) allows blood flow measurements in short time intervals. By combining the use of ${ }^{82} \mathrm{Rb}$ with pharmacologic stress testing, regional myocardial flow reserve can be evaluated in about 1 hour, which compares very favorably with the time required for the acquisition of thallium-201 $\left({ }^{201} \mathrm{Tl}\right)$ or technetium$99 \mathrm{~m}\left({ }^{99 \mathrm{~m}} \mathrm{Tc}\right)$ isonitrile single-photon emission computed tomography (SPECT) stress studies.

The practical advantages of ${ }^{82} \mathrm{Rb}$ are somewhat offset by the physiologic and physical properties of this tracer. The myocardial extraction fraction of ${ }^{82} \mathrm{Rb}$ is lower than that of ${ }^{201} \mathrm{Tl}$, and it decreases considerably with increasing blood flow. Therefore, high flow rates produce inaccurate measurements due to the nonlinear relationship between ${ }^{82} \mathrm{Rb}$ tissue retention and blood flow. Furthermore, ${ }^{82} \mathrm{Rb}$ emits positrons with an energy of $3.3 \mathrm{MeV}$ that travel a longer distance than those of ${ }^{13} \mathrm{~N}$ or ${ }^{11} \mathrm{C}$ in tissue before they annihilate with electrons. Thus, the image resolution obtainable with ${ }^{82} \mathrm{Rb}$ is less than that available with $\left[{ }^{13} \mathrm{~N} \mathrm{NH}_{3}\right.$ (Table I). However, the loss of resolution by the high energy of ${ }^{82} \mathrm{Rb}$ positrons is small in comparison to the effect of cardiac motion on the spatial resolution of nongated cardiac images.

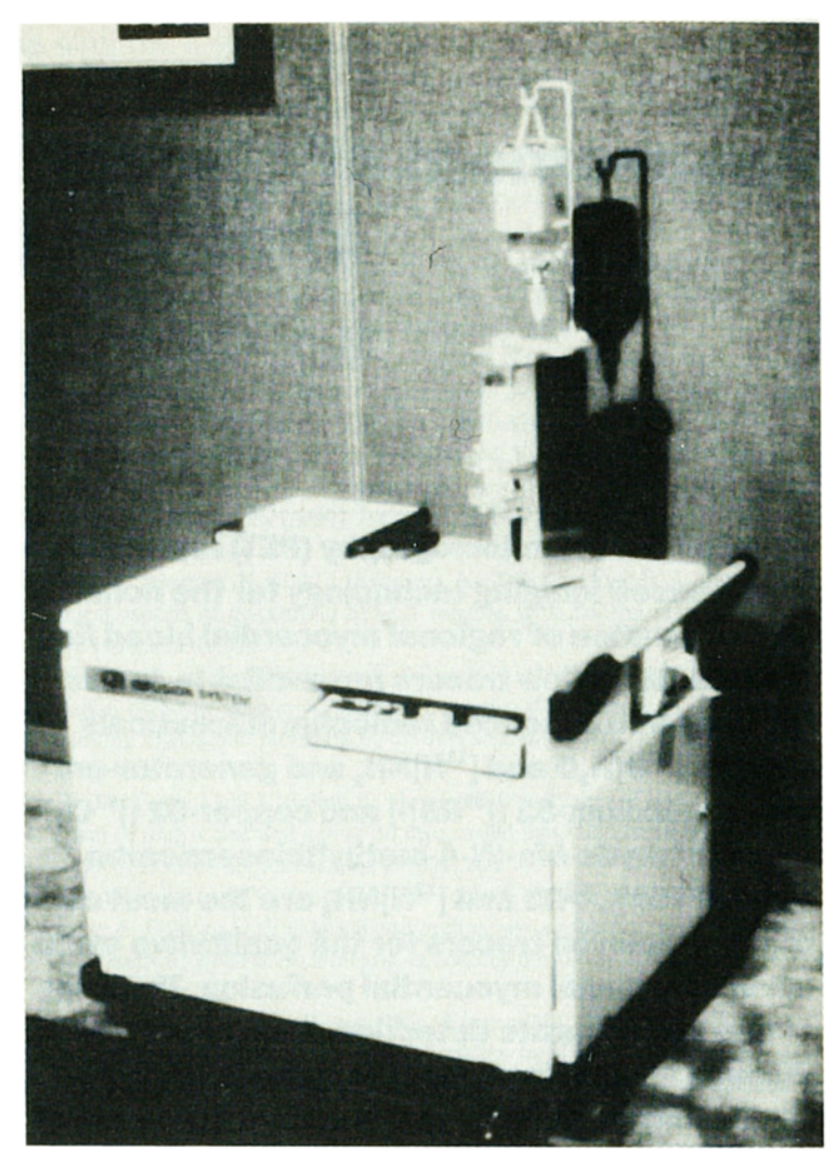

FIGURE $1{ }^{82}$ Sr $^{22}$ Pb generator mounted to a computer controlled Infusion system to allow convenlent adminlstration of the compound to the patient.

$\left[{ }^{62} \mathrm{Cu}\right]$ PTSM represents a newly introduced flow tracer produced with the zinc- $62\left({ }^{62} \mathrm{Zn}\right) /{ }^{62} \mathrm{Cu}$ generator. Although this radiotracer has been validated only in experimental studies, the preliminary results are promising. ${ }^{52} \mathrm{Cu}$ has a physical half-life of 9.8 minutes and, like ${ }^{82} \mathrm{Rb}$, exhibits a high positron energy (Table I). The myocardial extraction of PTSM is similar to that of ${ }^{82} \mathrm{Rb}$, and the clearance from myocardial tissue is slow-both desirable characteristics for blood flow imaging. The usable time period for a ${ }^{62} \mathrm{Zn} /{ }^{62} \mathrm{Cu}$ generator is only about 24 hours, in contrast to the ${ }^{82} \mathrm{Sr} /{ }^{82} \mathrm{Rb}$ generator, which has a shelf life of about 6 weeks. This may limit its distribution, as well as the availability of a continuous supply of compounds for the evaluation of myocardial blood flow. However, in combination with a centrally located cyclotron, generatorproduced flow tracers such as $\left[{ }^{82} \mathrm{Rb}\right]-$ or $\left[{ }^{62} \mathrm{Cu}\right] \mathrm{PTSM}$ can be combined with $\left[{ }^{18} \mathrm{~F}\right]$ deoxyglucose for the simultaneous evaluation of blood flow and tissue metabolism without the need of an on-site cyclotron.

Cyclotron-produced flow tracers: The cyclotron-produced tracers most commonly used for the evaluation of myocardial blood flow are $\left[{ }^{13} \mathrm{~N} \mathrm{NH}_{3}\right.$ 
and $\left[{ }^{15} \mathrm{O}_{\mathrm{H}_{2}} \mathrm{O}\right.$. Figure 2 shows the time course of both tracers in myocardial tissue and blood pool, following an intravenous bolus injection. The compound $\left[{ }^{13} \mathrm{~N}\right] \mathrm{NH}_{3}$ has a physical half-life of $10 \mathrm{~min}$, is avidly taken up by the myocardium, and clears rapidly from the blood pool. It enters the extravascular space and is converted in myocardial tissue to $\left[{ }^{13} \mathrm{~N}\right]$ glutamine. ${ }^{6}$ The clearance half-time of ${ }^{13} \mathrm{~N}$ from the myocardium is slow, and yields a high contrast between myocardial and blood activity. The retention of ${ }^{13} \mathrm{~N}$ in myocardium represents a combination of delivery (blood flow) and metabolic incorporation. These physiologic and physical properties of $\left[{ }^{13} \mathrm{~N}\right] \mathrm{NH}_{3}$ provide excellent image quality in combination with PET.

In patients with severely impaired left ventricular function or a history of heavy smoking a considerable amount of $\left[{ }^{13} \mathrm{~N}\right] \mathrm{NH}_{3}$ is retained in lung tissue, thus decreasing the heart-to-lung activity ratio. In contrast to ${ }^{82} \mathrm{Rb},\left[{ }^{13} \mathrm{~N} \mathrm{NH}_{3}\right.$ is avidly taken up by the liver and may, therefore, affect the

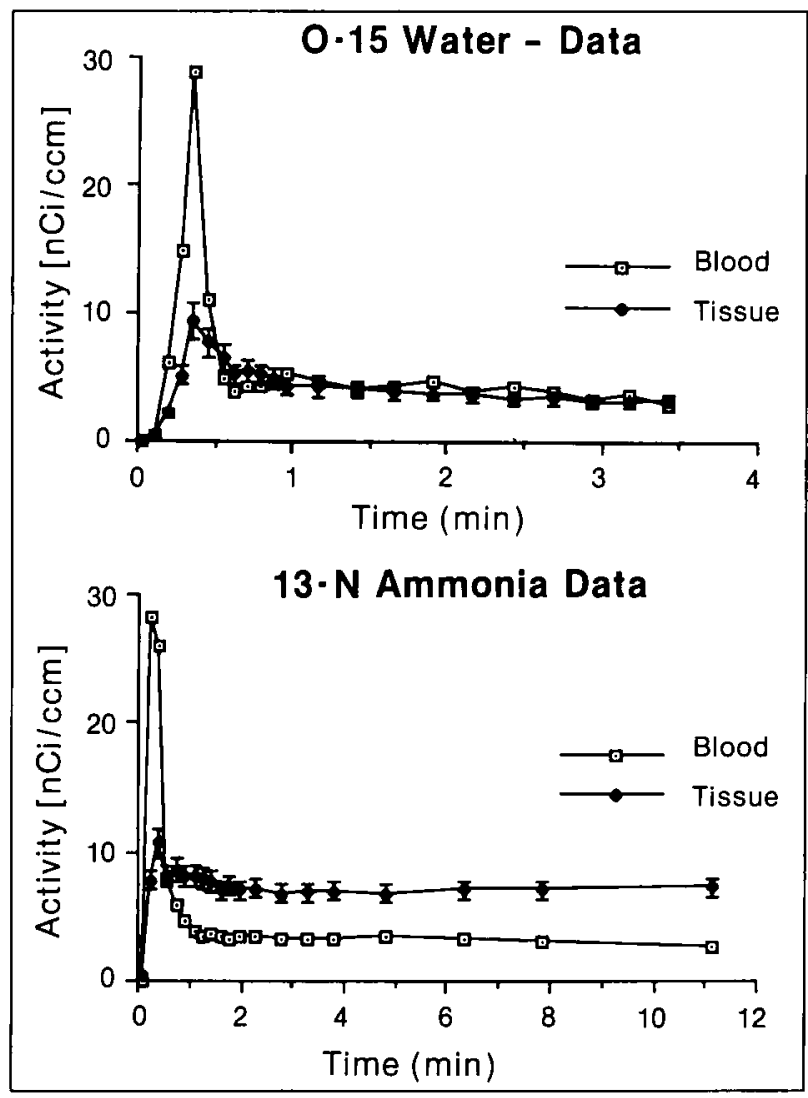

FCURE 2. Comparison of myocardial and blood pool timeacthilty curves obtained using $\left[{ }^{11} \mathrm{O}\right] \mathrm{H}_{2} \mathrm{O}$ (above) and $\left[{ }^{13} \mathrm{~N}_{\mathrm{NH}} \mathrm{N}_{3}\right.$ (bolow). The arterlal input curve (squares) represents blood pool acthity and is similar for both tracers. The tlssuve curve (clrcles) for [ ${ }^{13} \mathrm{~N}^{\mathrm{N}} \mathrm{NH}_{3}$ demonstrates retenthon of the tracer, ylelding high contrast between myocardlal and blood acthitty as earfy as $1 \mathrm{~min}$ after Injection. In contrast, the $\left[{ }^{15} \mathrm{O}\right] \mathrm{H}_{2} \mathrm{O}$ tlosue activity curve shows Itttle contrast to blood activity due to rapld back diffusion of the tracer from tissue. evaluation of the inferior wall of the left ventricle if the liver is in close proximity to cardiac tissue.

The compound $\left[{ }^{15} \mathrm{O} \mathrm{H}_{2} \mathrm{O}\right.$ represents a metabolically inert flow tracer. It diffuses freely across membranes and is highly extracted by myocardial tissue. Animal studies have shown a stable single first-pass extraction of $\left[{ }^{15} \mathrm{O}\right] \mathrm{H}_{2} \mathrm{O}$ over a wide flow range, indicating ideal physiologic characteristics of this tracer ${ }^{22}$ However, $\left[{ }^{15} \mathrm{O}^{2} \mathrm{H}_{2} \mathrm{O}\right.$ retained in myocardium diffuses rapidly back into the vascular space. Thus, the contrast between ${ }^{15} \mathrm{O}$ activity in the vascular space and myocardial tissue is small. In fact, the concentration ratio of blood to tissue reaches unity within 60-90 seconds after injection, depending on blood flow (Figure 2). Most studies employing $\left[{ }^{15} \mathrm{O}\right] \mathrm{H}_{2} \mathrm{O}$ for the evaluation of myocardial perfusion are using a separate imaging procedure with $\left[{ }^{15} \mathrm{O}\right]$ carbon monoxide, which labels red blood cells, and thus allows for the delineation of the vascular space within the myocardium and the ventricular chambers. By combining both approaches, the vascular activity can be subtracted and regional myocardial $\left[{ }^{15} \mathrm{O}\right] \mathrm{H}_{2} \mathrm{O}$ retention visualized. This dual tracer approach may limit the clinical application of $\left[{ }^{15} \mathrm{O}\right] \mathrm{H}_{2} \mathrm{O}$ studies because blood pool scans are required under both resting and stress conditions.

Besides $\left[{ }^{15} \mathrm{O}\right] \mathrm{H}_{2} \mathrm{O}$ and $\left[{ }^{13} \mathrm{~N}\right] \mathrm{NH}_{3},{ }^{11} \mathrm{C}$ or galliumlabeled $\left({ }^{68} \mathrm{Ga}\right)$ microspheres have been used for the assessment of myocardial perfusion. This tracer approach is limited to the injection of the tracer either into the left atrium or left ventricle, which is only possible in the catheterization laboratory.

\section{QUALTATIVE EVALUATION OF MYOCARDIAL PERFUSION}

Qualitative evaluation of regional tracer distribution using ${ }^{82} \mathrm{Rb}$ and ${ }^{13} \mathrm{~N}$ has been employed to detect CAD. Taking advantage of the attenuation correction provided by PET, relative tracer concentration is more homogeneous throughout crosssectional images of normal myocardium, as compared to ${ }^{201} \mathrm{TI}$ SPECT imaging (Figure 3 ). Recently published normal data for regional ${ }^{201} \mathrm{Tl}$ retention on SPECT images demonstrate considerable variation between the anterior and inferior walls of the left ventricle in a male population, thus indicating the significant effect of photon attenuation. ' Attenuation artifacts are common with ${ }^{201} \mathrm{Tl}$ SPECT imaging and may limit the specificity of this test for the diagnosis of $\mathrm{CAD}$.

PET evaluation of myocardial perfusion at rest and during stress provides detection of regional perfusion abnormalities with high diagnostic accuracy (Figure 4). Most stress flow studies are per- 


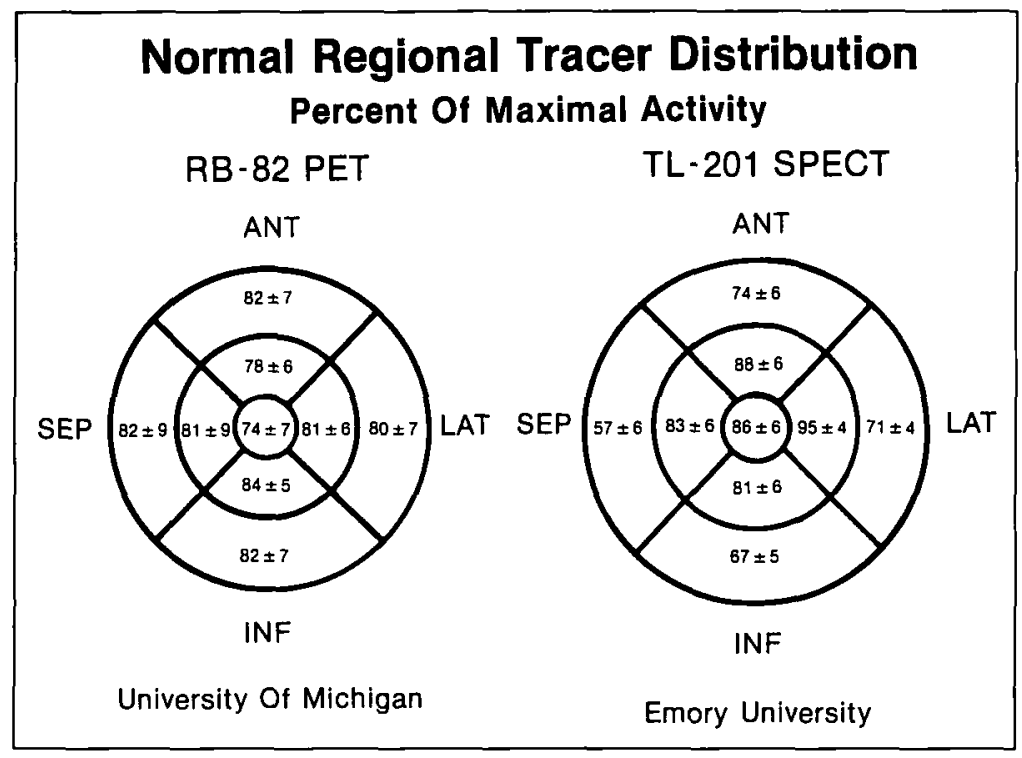

FICURE 3. Compartson of normal distributhon of ${ }^{82} \mathrm{Fb}$ and ${ }^{201} \mathrm{~T}$ on a polar map dleplay representing regional relative tracer concentration expressed as percent of maxlmal acthity. Data represent averase of 15 ${ }^{82} \mathrm{Fob}$ studies (8 male, 7 femalo) following Intravenous dipyridamole Infuslon. Note the decreased relattve ${ }^{201}$ in actulty in the Imforolateral wall representing soft thesue attenuation. Thallium-201 data adapted from the Joumal of Nuclear Medicline.

formed following pharmacologic coronary vasodilatation (dipyridamole, adenosine) because the combination of PET with exercise poses technical difficulties, especially if the short-lived tracer ${ }^{82} \mathrm{Rb}$ is employed. Table II depicts recently published diagnostic results using $\left[{ }^{13} \mathrm{~N}\right] \mathrm{NH}_{3}$ or ${ }^{82} \mathrm{Rb}$ in combination with PET. Schelbert et $\mathrm{al}^{8}$ demonstrated that use of $\left[{ }^{13} \mathrm{~N}\right] \mathrm{NH}_{3}$ provides sensitive detection of CAD. Gould et al. ${ }^{9}$ employed ${ }^{82} \mathrm{Rb}$ in combination with dipyridamole in a larger group of patients with suspected $C A D$, and reported a high sensitivity and specificity for the detection of disease. Demer et al. ${ }^{10}$ extended this study to 193 patients. The noninvasive assessment of relative coronary reserve by ${ }^{82} \mathrm{Rb}$ PET correlated closely with the angiographic definition of the severity of CAD employing quantitative measurements. These results suggest an excellent diagnostic performance of PET flow imaging for the detection of CAD.
Only a few studies directly compared PET flow imaging with ${ }^{201} \mathrm{Tl}$ SPECT in the same patient population. Tamaki et al. ${ }^{11}$ employed $\left[{ }^{13} \mathrm{~N}^{2} \mathrm{NH}_{3}\right.$ PET imaging together with ${ }^{201} \mathrm{Tl}$ SPECT in patients with angiographically proven $\mathrm{CAD}$. Both imaging procedures yielded a high sensitivity for the regional detection of disease. However, this study did not include a normal control population; thus, no conclusions can be drawn about the specificity of both imaging modalities.

More recently, two investigations compared ${ }^{82} \mathrm{Rb}$ PET imaging with ${ }^{201} \mathrm{Tl}$ SPECT imaging in the same patient population. In the first study of 132 patients, Go et al $^{12}$ from the Cleveland Clinic reported a significantly higher diagnostic accuracy of ${ }^{82} \mathrm{Rb}$ PET imaging for the detection of CAD. Sensitivity and specificity of ${ }^{82} \mathrm{Rb}$ PET were higher than those of ${ }^{201} \mathrm{Tl}$ SPECT and yielded a significantly improved diagnostic accuracy of $92 \%$ for

\section{RB 82 PET \\ Coronary Artery Disease \\ (2149128)}

Stress

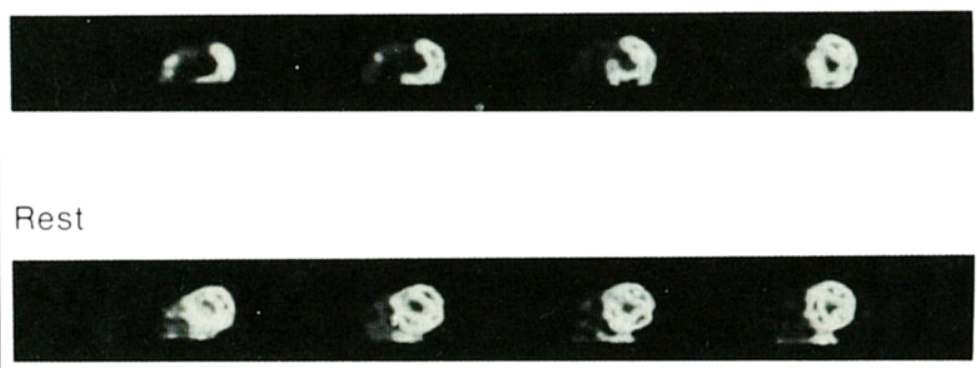

University Of Michigan
FICURE 4. Cross-sectional ${ }^{\text {*at }}$ Images of patient with significant left anterior doscending artery (LAD) stenosis. The resting study below shows homogenous myocardlal ${ }^{2} \mathbf{F b}$ acthitty. Following Intravenous dipyridamole Infusion, a marked perfuslon abnormality is noted in the anteroseptal wall consistent with Impaired coronary reserve in the LAD teriftory. Note the dilatation of left ventricular chamber as indirect ovidence of the significance of the dipyridamole-induced perfusion abnormallty. 


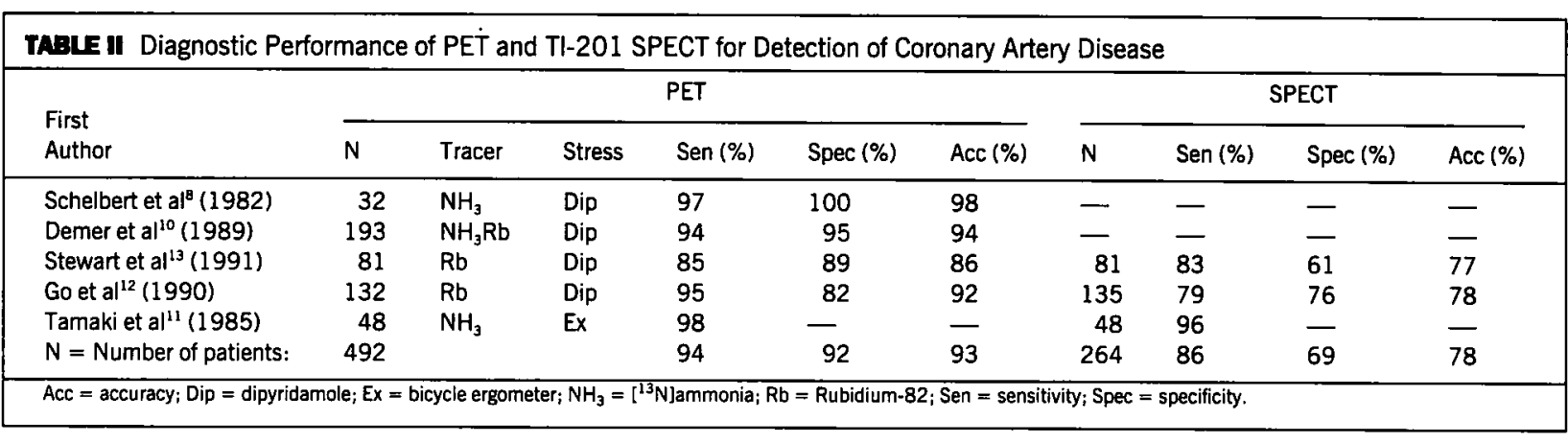

PET as compared with $76 \%$ for SPECT. Both imaging procedures followed a single infusion of dipyridamole, thus avoiding the variability of repeated stress testing in the study population. The results of the second study, performed at the University of Michigan, failed to confirm the higher sensitivity of ${ }^{82} \mathrm{Rb}$ PET for detection of CAD. ${ }^{13}$ Both PET and SPECT identified disease correctly in about $85 \%$ of the cases. However, PET significantly out-performed SPECT in terms of specificity (Table II). The overall diagnostic accuracy of PET and SPECT agreed closely with the data obtained by Go et al. ${ }^{12}$ Although patient selection for cardiac catheterization may explain the low specificity of ${ }^{201} \mathrm{Tl}$ SPECT described by the Michigan study, several recent studies indicate the relatively high incidence of false-positive ${ }^{201} \mathrm{Tl}$ SPECT results. ${ }^{14,15}$ ${ }^{82} \mathrm{Rb}$ PET showed a significantly lower rate of false-positive findings in the same patient population. The diagnostic difference was most obvious in the diagnosis of disease involving the inferior wall of the left ventricle. Diaphragmatic attenuation artifacts appear to be less common with ${ }^{82} \mathrm{Rb}$ PET imaging, which clearly indicates the limitations of the low energy tracer ${ }^{201} \mathrm{Tl}$ for SPECT imaging. Future use of ${ }^{99 \mathrm{~m}} \mathrm{Tc}$-labeled radiopharmaceuticals may overcome some of these limitations, but sophisticated attenuation correction of SPECT images may be required to match the advanced imaging technology provided by PET instrumentation.

Thus, PET in combination with ${ }^{82} \mathrm{Rb}$ or $\left[{ }^{13} \mathrm{~N}\right] \mathrm{NH}_{3}$ yields higher diagnostic accuracy for detection of CAD as compared to ${ }^{201} \mathrm{Tl}$ SPECT. This primarily reflects the improvement of scintigraphic data acquisition provided by PET. Preliminary studies analyzing the cost of PET imaging and its impact on the management of patients with proven or suspected CAD suggest an overall cost-saving effect due to less unnecessary cardiac catheterization. ${ }^{16}$ However, the question remains whether the higher diagnostic accuracy of this modality justifies the increased costs involved with this test. Further investigation will define the economic cost-benefit ratio of $\mathrm{PET}$ flow imaging for detection of $\mathrm{CAD}$.

\section{QUANTIFICATION OF MYOCARDIAL BLOOD FLOW BY PET}

As outlined above, PET provides the most sophisticated technology to quantify regional tracer concentration in the myocardium. The time course of tracer distribution in myocardium and blood can be defined by using dynamic image acquisition. The most commonly used flow tracers are $\left[{ }^{13} \mathrm{~N}\right] \mathrm{NH}_{3}$ and $\left[{ }^{15} \mathrm{O}\right] \mathrm{H}_{2} \mathrm{O}$. In order to quantify myocardial blood flow in units of $\mathrm{ml} / \mathrm{min} / 100 \mathrm{~g}$, the accumulation and fate of the radiopharmaceutical in myocardial tissue must be described by appropriate mathematical models. The exchange of tracer between vascular space and tissue is commonly described in terms of compartmental models. These models rely on two basic assumptions: first, the tracer is homogeneously distributed in these compartments; and second, the transfer from compartments occurs with conservation of mass. Theory and application of compartmental analysis require the development of a current model for the behavior of any particular tracer in the biologic system. Knowledge about the physiologic behavior of the tracer should provide justification for the specific structure as well as the parameters of the compartmental model.

The configurations of compartmental models used frequently for quantification of blood flow are shown in Figure 5. The two-compartmental model consists of a vascular as well as an extravascular compartment. It is most applicable to the description of the tracer kinetics of freely diffusable blood flow tracers such as $\left[{ }^{15} \mathrm{O}\right] \mathrm{H}_{2} \mathrm{O}$. The injected tracer is delivered by the vascular space, diffuses immediately across the membrane, and equilibrates within the tissue. The exchange between the two compartments is expressed by the rate constants $K_{1}$ and $k_{2}$. In case of freely diffusable tracers, values for blood flow are usually derived from the estimation of $k_{2}$, which represents the clearance of activity from tissue. $^{17}$

In contrast, the description of tissue kinetics for $\left[{ }^{13} \mathrm{~N}\right] \mathrm{NH}_{3}$ requires a more complex three-compartmental model (Figure 5). The vascular compartment represents the tracer concentration in plasma 
Model For 0.15 Water Flow Determination

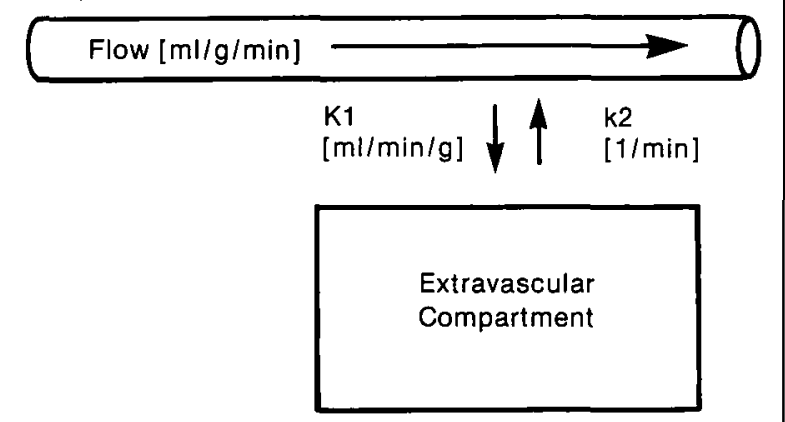

Model For N-13 Ammonia Flow Determination

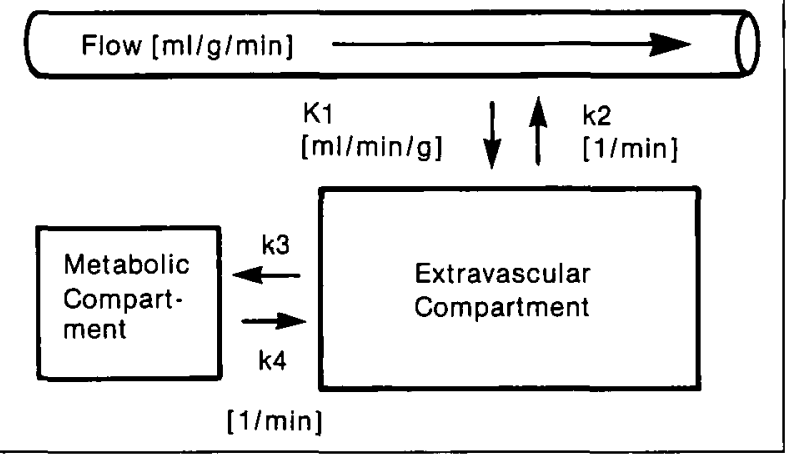

FIURE 5. Tracer kInetlc models employed for determination of blood flow using PET data. The model used for $\left[{ }^{15} \mathrm{O}\right] \mathrm{H}_{2} \mathrm{O}$ (above) ls based on the princlple of Inert gas exchange and can be described by a single tissue, 2-compartmental model. ${ }^{17}$ The filow (F) is computed from the washout rate constant $k_{2}$ according to the formula $k_{2}=$ $F / p$, where p represents the parttion coefficlent of water between blood and tlssue. The myocardlal retention of [ $\left.{ }^{13} \mathrm{~N}\right] \mathrm{NH}_{3}$ depends on Its metabolic incorporation Into giutamine via the glutamate-glutamine patinway. A 3-compartmental model including the rate constants $K_{1}, K_{2}$, and $k_{3}$ has to be used to separate Intilal extraction from backdiffusion $\left(k_{2}\right)$ and retention $\left(k_{3}\right) . K_{1}$ is usually written with a capital lotter in order to ind cate that $i t$ expresses a clearance rate constant rather than a transfer rate constant. The plasma activity concentration has the dimension $\mu \mathrm{mol} / \mathrm{ml}$ and the activity concentration in tissue the dlmenslon $\mu \mathrm{mol} / \mathrm{g}$, where $K_{1}$ is expressed in ml/min/100 g as an Index of myocardlal blood flow. The rate constants $k_{2}-k_{4}$ are expressed in $\mathrm{min}^{-1}$.

of the coronary capillaries. The two extravascular compartments represent different chemical states of the tracer but do not distinguish between anatomically separable spaces. Within the extravascular compartment, the tracer competes for back diffusion into the vascular space $\left(k_{2}\right)$ and transfer into the metabolic compartment $\left(k_{3}\right)$. In the case of $\left[{ }^{13} \mathrm{~N}\right] \mathrm{NH}_{3}$, the label is trapped in the myocardium in the form of $\left[{ }^{13} \mathrm{~N}\right]$ glutamine. ${ }^{18}$ The release of ${ }^{13} \mathrm{~N}$ activity from myocardium is very slow. Therefore, for the description of $\left[{ }^{13} \mathrm{~N}\right] \mathrm{NH}_{3}$ kinetics, $k_{4}$ (describing the metabolism of $\left[{ }^{13} \mathrm{~N}\right]$ glutamine) can be neglected in view of the short physical half-life of $\left[{ }^{13} \mathrm{~N}\right] \mathrm{NH}_{3}$ (10 minutes). In this model, the blood flow equals $K_{1}$ times the single-pass extraction fraction of the tracer. $\left[{ }^{13} \mathrm{~N}\right] \mathrm{NH}_{3}$ is extracted from blood with a high extraction fraction. ${ }^{3}$ Based on experimental data by Schelbert et al. ${ }^{18}$ the singlepass extraction fraction only slightly decreases in high-flow states, and is assumed to be greater than $90 \%$, even for flow values up to $500 \mathrm{ml} / \mathrm{min} / 100 \mathrm{~g}$ of tissue. However, the net retention of $\left[{ }^{13} \mathrm{~N}^{-} \mathrm{NH}_{3}\right.$ in myocardial tissue depends on flow and the metabolic incorporation of $\left[{ }^{13} \mathrm{~N}\right] \mathrm{NH}_{3}$. Because not all of the activity entering the extravascular compartment is metabolized, the assessment of flow based on retained $\left[{ }^{13} \mathrm{~N}\right] \mathrm{NH}_{3}$ activity underestimates myocardial blood flow. This is most apparent during high-flow states where $k_{3}$ becomes the rate-limiting step for the incorporation of the label into the metabolic compartment. Thus, to minimize underestimation of high flow states, a tracer kinetic model separating $K_{1}$ and $k_{3}$ is necessary. Detailed descriptions of the tracer kinetic models employed for $\left[{ }^{15} \mathrm{O}\right] \mathrm{H}_{2} \mathrm{O}$ and $\left[{ }^{13} \mathrm{~N}\right] \mathrm{NH}_{3}$ are provided by Hutchins et al, ${ }^{3}$ Iida et al,${ }^{19}$ Krivokapich et al,${ }^{20}$ and Bergmann et al. ${ }^{2}$

\section{COMPARISON OF $\left[{ }^{13} \mathrm{~N}^{-\mathrm{NH}_{3}}\right.$ AND $\left[{ }^{15} \mathrm{O}_{3} \mathrm{H}_{2} \mathrm{O}\right.$ QUANTITATIVE FLOW MEASUREMENTS:}

Both $\left[{ }^{13} \mathrm{~N}\right] \mathrm{NH}_{3}$ and $\left[{ }^{15} \mathrm{O}\right] \mathrm{H}_{2} \mathrm{O}$ have inherent physiologic and physical advantages and disadvantages as imaging agents. $\left[{ }^{13} \mathrm{~N}\right] \mathrm{NH}_{3}$ kinetics in myocardium are more complex than those of $\left[{ }^{15} \mathrm{O}_{3} \mathrm{H}_{2} \mathrm{O}\right.$, but the longer physical half-life of $\left[{ }^{13} \mathrm{~N}\right] \mathrm{NH}_{3}$ and retention in myocardial tissue make it a superior imaging agent. On the other hand, $\left[{ }^{15} \mathrm{O}\right] \mathrm{H}_{2} \mathrm{O}$ exhibits almost ideal physiologic properties as a flow tracer. However, its short physical half-life and high activity in the vascular space are challenging for current imaging instrumentation. As a result, different kinetic models must be used for quantification of blood flow based on $\left[{ }^{13} \mathrm{~N}\right] \mathrm{NH}_{3}$ or $\left[{ }^{15} \mathrm{O}\right] \mathrm{H}_{2} \mathrm{O}$ kinetics.

As discussed above, the difference between both tracer kinetic models can be expressed by specific rate constants that describe myocardial blood flow. In the case of $\left[{ }^{13} \mathrm{~N}\right] \mathrm{NH}_{3}$, the rate constant $K_{1}$ is used, while the washout rate constant $k_{2}$ describes blood flow in the $\left[{ }^{15} \mathrm{O} \mathrm{H}_{2} \mathrm{O}\right.$ model. At different physiologic and pathophysiologic states, $K_{1}$-based flow measurements are sensitive to changes of the extraction fraction. ${ }^{21}$ Estimates of myocardial blood flow by the $\left[{ }^{15} \mathrm{O}_{3} \mathrm{H}_{2} \mathrm{O}\right.$ method reflect $k_{2}$ and the partition coefficient of water among plasma, red blood cells, and myocardial tissue, which may also vary under different pathophysiologic conditions. ${ }^{22}$ In contrast to the metabolically inert $\left[{ }^{15} \mathrm{O}\right] \mathrm{H}_{2} \mathrm{O},\left[{ }^{13} \mathrm{~N}^{2} \mathrm{NH}_{3}\right.$ is rapidly metabolized in the liver following intravenous injection, and ${ }^{13} \mathrm{~N}$-labeled metabolites appear rapidly in 
blood. ${ }^{6}$ The quantification of regional myocardial blood flow by $\left[{ }^{13} \mathrm{~N}\right] \mathrm{NH}_{3}$ requires the definition of the arterial input function. Pecent studies indicate that the effect of ${ }^{13} \mathrm{~N}$ metabolites in blood on myocardial blood flow measurements is relatively small, and correction for metabolic contamination may not be necessary. ${ }^{3}$

The major advantage of $\left[{ }^{15} \mathrm{O}_{3} \mathrm{H}_{2} \mathrm{O}\right.$ is that blood flow measurements are less affected by partial volume effect. The spatial resolution provided by current PET instrumentation ranges between 6 and $10 \mathrm{~mm}$. In the human heart, the left ventricular wall thickness averages between 10 to $20 \mathrm{~mm}$, depending on the degree of wall thickening during the cardiac cycle. Thus, the recovery of tracer information from the left ventricular wall is influenced by partial volume effect. Undersampling becomes most prominent if the left ventricular wall is thinned, such as in patients with previous myocardial infarction or severe contractile dysfunction. ${ }^{23}$ Because flow measurements with $\left[{ }^{15} \mathrm{O}\right] \mathrm{H}_{2} \mathrm{O}$ are based on the washout of activity (relative change of activity), the partial volume effect is less important for the accurate estimate of clearance kinetics. Conversely, $\left[{ }^{13} \mathrm{~N}\right] \mathrm{NH}_{3}$ flow measurements depend on the accurate estimate of the initial uptake of this tracer in the myocardium. These measurements are sensitive to the partial volume effect. ${ }^{24,25}$ Thus, in areas of previous myocardial infarction, it is expected that $\left[{ }^{13} \mathrm{~N}\right] \mathrm{NH}_{3}$ blood flow measurements will underestimate the true myocardial blood flow.

Although clearance kinetics are less sensitive to partial volume effects, Monte-Carlo simulations have shown that the coefficient of variation for a washout rate constant is about 3 times higher than the same coefficient for an uptake rate constant. It is obvious that further research is required to define the relative error sensitivity of uptake parameters $\left(\left[{ }^{13} \mathrm{~N}\right] \mathrm{NH}_{3}\right)$ and washout parameters $\left(\left[{ }^{15} \mathrm{O}\right] \mathrm{H}_{2} \mathrm{O}\right)$ under various physiologic and pathophysiologic conditions.

It is expected that myocardial blood flow can also be quantified using $\left[{ }^{82} \mathrm{Rb}\right]-$ and $\left[{ }^{62} \mathrm{Cu}\right]$ PTSM. Current research is focusing on the development of a kinetic model for ${ }^{82} \mathrm{Rb}$. The kinetics of ${ }^{82} \mathrm{Rb}$ resemble those of ${ }^{201} \mathrm{Tl}$. However, the short half-life of this tracer requires PET instrumentation with high sensitivity and count-rate capabilities for the accurate definition of time-activity curves.

\section{APPLICATION OF QUANTITATIVE FLOW MEASUREMENTS BY PET}

Shah et $\mathrm{al}^{26}$ compared the retention of $\left[{ }^{13} \mathrm{~N}\right] \mathrm{NH}_{3}$ in canine myocardium with blood flow as assessed by radiolabeled microspheres. As expected, a nonlinear relationship between both measurements was observed. This accompanied a significant underestimation of myocardial blood flow based on the retained $\left[{ }^{13} \mathrm{~N}^{-\mathrm{NH}_{3}}\right.$ activity at high-flow states (Table III). With the introduction of a tracer kinetic model that corrects for the decreasing retention fraction at high flows, a linear relationtiship between $\left[{ }^{13} \mathrm{~N}\right] \mathrm{NH}_{3}$ and microspheres blood flow could be demonstrated over a wide flow range. ${ }^{27}$

Bergmann et al. ${ }^{2}$ validated $\left[{ }^{15} \mathrm{O}\right] \mathrm{H}_{2} \mathrm{O}$ flow measurements in the canine model. Again, comparing scintigraphic measurements with microspheres blood flow, these investigators demonstrated a linear relationship between both measurements over a flow range from 30 to $500 \mathrm{ml} / \mathrm{min} / 100 \mathrm{~g}$ (Table III). The correlation coefficient for both measurements was 0.95 , which indicates the accuracy of these measurements in the animal model.

Quantitative measurements of regional myocardial blood flow in human myocardium have been performed with both $\left[{ }^{13} \mathrm{~N}\right] \mathrm{NH}_{3}$ and $\left[{ }^{15} \mathrm{O}\right] \mathrm{H}_{2} \mathrm{O}$. Blood flow measurements at rest and following pharmacologic stress are in close agreement with data previously obtained by coronary sinus catheterization or Doppler flow catheters (Table IV). The relative increase of myocardial blood flow (coronary reserve) in normal volunteers was greater than 4 to 1 , which again agrees closely with independent measures of coronary reserve by Doppler catheters and studies performed in the animal model. ${ }^{1}$ Quantitative flow measurements during stress (Table IV) indicate that the increase in myocardial blood flow is greater following dipyridamole infusion than following exercise. This may reflect the difficulty of reaching adequate cardiac workload with bicycle exercise during PET imaging. ${ }^{20}$

The noninvasive determination of coronary reserve by pharmacologic means may provide a useful and reproducible parameter for the func-

\begin{tabular}{|lllll|}
\hline TABLE III Correlation of PET and Microspheres Flow Measurements in Canine Myocardium \\
\hline \\
Author & Tracer & $\begin{array}{l}\text { Flow Range } \\
\text { [ml/min/100 g] }\end{array}$ & Correlation \\
\hline Bellina et al $\left.\right|^{27}(1990)$ & ${ }^{13} \mathrm{NH}_{3}$ & $20-500$ & $y=-0.18+1.08 x$ & $(\mathrm{R}=0.96)$ \\
Bergmann et $\mathrm{al}^{2}(1989)$ & $\mathrm{H}_{2}{ }^{150}$ & $29-504$ & $y=0.00+1.06 x$ & $(\mathrm{R}=0.95)$ \\
Shah et al ${ }^{26}(1985)$ & ${ }^{13} \mathrm{NH}_{3}$ & $44-200$ & $y=-36.2+1.53 x-0.0027 x^{2}$ & $(\mathrm{R}=0.94)$ \\
\hline
\end{tabular}




\begin{tabular}{|c|c|c|c|c|c|}
\hline Author & Tracer & $\begin{array}{l}\text { Rest Flow } \\
{[\mathrm{ml} / \mathrm{min} / 100 \mathrm{~g}]}\end{array}$ & $\begin{array}{l}\text { Stress Flow } \\
{[\mathrm{m} / / \mathrm{min} / 100 \mathrm{~g}]}\end{array}$ & Stress/Rest & Stress \\
\hline Araujo et $a^{28}(1990)$ & $\mathrm{H}_{2}{ }^{150}$ & $\begin{array}{l}88 \pm 8 \\
93 \pm 21^{*}\end{array}$ & $\begin{array}{l}352 \pm 112 \\
132 \pm 27^{*}\end{array}$ & $\begin{array}{l}4.00 \\
1.42^{*}\end{array}$ & Dipyridamole \\
\hline $\begin{array}{l}\text { Bergmann et al }{ }^{2}(1989) \\
\text { Hutchins et al }{ }^{3}(1990)\end{array}$ & $\begin{array}{l}\mathrm{H}_{2}{ }^{15} \mathrm{O} \\
{ }^{13} \mathrm{NH}_{3}\end{array}$ & $\begin{array}{l}90 \pm 22 \\
88 \pm 17\end{array}$ & $\begin{array}{l}355 \pm 115 \\
417 \pm 112\end{array}$ & $\begin{array}{l}3.94 \\
4.74\end{array}$ & $\begin{array}{l}\text { Dipyridamole } \\
\text { Dipyridamole }\end{array}$ \\
\hline Krivokapich et al ${ }^{33}$ (1989) & ${ }^{13} \mathrm{NH}_{3}$ & $70 \pm 17$ & $135 \pm 22$ & 1.93 & Bicycle ergometer \\
\hline
\end{tabular}

tional assessment of severity of CAD. Results by Araujo et $\mathrm{al}^{28}$ and Walsh et $\mathrm{al}^{29}$ indicate that the regional coronary reserve is markedly decreased in poststenotic ventricular segments. Walsh et $\mathrm{al}^{29}$ studied patients undergoing coronary angioplasty prior to and following this procedure. The coronary reserve averaged 1.3 in the stenotic area prior to angioplasty but increased to $3.3,5$ days after revascularization. Thus, quantitative flow measurements may be used following angioplasty for the objective assesment of the intervention results, and also as a predictive parameter for restenosis.

In addition to useful diagnostic and prognostic information in patients with $\mathrm{CAD}$, quantitative flow measurements can also provide an objective assessment of drug therapy. Such measurements can also be applied in cardiac diseases characterized by global changes in blood flow.

Flow measurements based on relative tracer distribution are of limited use in such disease groups. In patients with chest pain and normal coronary arteries, $\left[{ }^{15} \mathrm{O}\right] \mathrm{H}_{2} \mathrm{O}$ blood flow measurements have been shown to identify decreased coronary reserve. ${ }^{30}$ Thus, among angina patients, PET may provide a unique diagnostic means to identify those patients with presumably smallvessel CAD.

Quantitative flow measurements have also been employed in patients with cardiac transplants. ${ }^{31}$ Few studies have suggested that the coronary reserve is reduced in patients with transplant rejection. This indicates altered coronary hemodynamics, with further studies required to define the diagnostic yield of such measurements in the follow-up of patients with cardiac transplantation.

Although the coronary reserve represents a sophisticated tool to describe the functional state of the coronary vasculature, its magnitude is affected by physiologic processes. For example, elevated blood pressure and heart rate increase resting blood flow and decrease coronary reserve. ${ }^{32} \mathrm{On}$ the other hand, pharmacologic action of dipyridamole or adenosine may be attenuated in some patients, especially if they take medications known to interact with these drugs. Therefore, the inter- pretation of flow measurements in patients with various cardiac diseases requires careful consideration of all factors which may affect the magnitude of global and regional coronary reserve.

\section{CONCLUSION}

PET provides an advanced imaging technology that allows the accurate definition of regional tracer distribution. This technology, in combination with ${ }^{82} \mathrm{Rb}$ and $\left[{ }^{13} \mathrm{~N}\right] \mathrm{NH}_{3}$, allows for the sensitive and specific detection of CAD. Several studies indicate the superiority of this approach in comparison to standard ${ }^{201} \mathrm{TI}$ SPECT imaging. However, further studies are needed to define the costbenefit ratio of this technology for the management of patients with suspected or proven CAD.

PET represents the most accurate noninvasive means to measure regional blood flow and can be used in combination with pharmacologic stress tests to quantify regional coronary reserve. Tracer kinetic models for $\left[{ }^{13} \mathrm{~N}\right] \mathrm{NH}_{3}$ and $\left[{ }^{15} \mathrm{O}\right] \mathrm{H}_{2} \mathrm{O}$ provide accurate flow estimates over a wide flow range. Quantitative flow measurements by PET provide a sophisticated tool for research and clinical characterization of patients with CAD. Short-lived radiopharmaceuticals used for PET allow the combined evaluation of flow and other tissue functions such as metabolism, which may prove useful in the assessment of the extent and severity of myocardial disease.

Acknowledgment: The authors thank Jennifer Hall for the preparation of the manuscript and Ngoc Nguyen for the preparation of the illustrations.

\section{REFERENCES}

1 Gould $\mathrm{K}$, Kirkeeide $\mathrm{R}$, Buchi $\mathrm{M}$. Coronary flow reserve as a physiologic measure of stenosis severity. J Am Coll Cardiol 1990;15:459-474.

2. Bergmann S, Herrero P, Markham J, Weinheimer C, Walsh M. Noninvasive quantification of myocardial blood flow in human subjects with oxygen-15-labeled water and positron emission tomography.J Am Coll Cardiol 1989;14:639-652.

3. Hutchins G, Schwaiger M, Rosenspire K, Krivokapich J, Schelbert H, Kuhl D. Noninvasive quantification of regional myocardial blood flow in the human hear using $\left[{ }^{13} \mathrm{~N}\right]^{*}$ ammonia and dynamic PET imaging. J Am Coll Cardiol 1990;15:10321042.

4. Yano Y, Cahoon J, Budinger T. A precision flow controlled ${ }^{\mathrm{K} 2} \mathrm{Rb}$ generator for bolus or constant-infusion studies of the heart and brain. J Nucl Med 1981;22:10061010 
5. Shelton $M$, Green $M$, Mathias $C$, Welch $M$, Bergmann S. Kinetics of copper-PTSM in isolated hearts: a novel tracer for measuring blood flow with positron emission tomography. J Nucl Med 1989;30:1843-1847.

6. Rosenspire K, Schwaiger M, Mangner T, Hutchins G, Sutorik A, Kuhl D. Metabolic fate of $\left[{ }^{13} \mathrm{~N}\right]^{*}$ ammonia in human and canine blood. $J$ Nucl Med 1990;31:163-167.

7. Eisner R, Tamas M, Cloninger K, Shonkoft D, Oates J, Gober A, Dunn D, Malko J, Churchwell A, Patterson R. Normal SPECT thallium-201 bull's-eye display: gender differences. $J$ NuCl Med 1988;29:1901-1909.

8. Schelbert H, Wisenberg G, Phelps M, Gould K, Eberhard H, Hoffman E, Gormesm A, Kuhl D. Noninvasive assessment of coronary stenosis by myocardial imaging during pharmacologic coronary vasodilation. VI. Detection of coronary artery disease in man with intravenous $\left.\left[{ }^{13} \mathrm{~N}\right]\right]^{*}$ ammonia and positron computed tomography. Am J Cardiol 1982;49:1197.

9. Gould K, Goldstein R, Mullani N, Kirkeeide R, Wong G, Smalling R, Fuentes F, Nishikawa A, Mathews W. Non-invasive assessment of coronary stenoses by myocardial perfusion imaging during pharmacologic coronary vasodilation. VIII. Clinical feasibility of positron cardiac imaging without a cyclotron using generatorproduced rubidium-82. J Am Coll Cardiol 1986;7:775.

10. Demer L, Gould K, Goldstein R, Kirkeeide R, Mullani N, Smalling R, Nishikawa A, Merhige $M$. Assessment of coronary artery disease severity by positron emission tomography. Comparison with quantitative arteriography in 193 patients. Circulation 1989;79:825.

11. Tamaki N, Yoekura Y, Senda M, Kureshi S, Saji H, Kodama S, Konishi $Y$, Ban T, Kambara H, Kawai C, Torizuka K. Myocardial positron computed tomography with ${ }^{13} \mathrm{~N}$ ammonia at rest and during exercise. Eur $J$ Nucl Med 1985;11:246.

12. Go RT, Marwick TH, Macintyre WJ, Gopal BS, Neumann DR, Underwood DA, Simpfendorfer CC. A prospective comparison of rubidium-82 PET and thallium-201 SPECT myocardial perfusion imaging utilizing a single dipyridamole stress in the diagnosis of coronary artery disease. J Nucl Med 1990;31:1899-1905. 13. Stewart RE, Schwaiger M, Molina E, Popma J, Gacioch GM, Kalus M, Squicciarini S, Al-Aouar ZR, Schork A, Kuhl DE. Comparison of rubidium-82 positron emission tomography and thallium-201 SPECT imaging for the detection of coronary artery disease. Am J Cardiol 1991 (in press).

14. Iskandrian A, Heo J, Kong $B$, Lyons $E$. Effect of exercise level on the ability of Tl-201 tomographic imaging in detecting coronary artery disease: analysis of 461 patients. J Am Coll Cardiol 1989; 14:1477-1486.

15. Gould $\mathrm{K}$. How accurate is thallium exercise testing for diagnosis of coronary artery disease? J Am Coll Cardiol 1989;14:1487-1490.

16. Gould K, Mullani B, William M. PET, PTCA, and economic priorities. Clin Cardiol 1990;13:153-164.

17. Kety $S$. Measurement of local blood flow by the exchange of an inert, diffusable substance. Methods Med Res 1960;8:228-236.

18. Schelbert H, Phelps M, Huang S, MacDonald N, Hansen H, Selin C, Kuhl D. $\left[{ }^{13} \mathrm{~N}\right]^{*}$ ammonia as an indicator of myocardial blood flow. Circulation 1981;63:1259 1272 .
19. Iida H, Takahashi A, Ono Y, Kanno I, Miura S, Murakami M, Takahashi K. Measurement of absolute myocardial blood flow with $\mathrm{H}_{2}{ }^{15} \mathrm{O}$ and dynamic PET. Circulation 1988;78:104-115.

20. Krivokapich J, Smith G, Huang S, Hoffman E, Ratib O, Phelps M, Schelber H. $\left[{ }^{13} \mathrm{~N}\right]^{*}$ ammonia myocardial imaging at rest and with exercise in normal volunteers. Quantification of absolute myocardial perfusion with dynamic positron emission tomography. Circulation 1989;80:1328-1337.

21. Bergmann $S$, Hack $S$, Tewson $M$, Welch $M$, Sobel $R$. The dependence of accumulation of ${ }^{13} \mathrm{NH}_{3}$ by myocardium on metabolic factors and its implications for the quantitative assessment of perfusion. Cinculation 1980;61:34-43.

22. Bergmann S, Fox K, Rand A, McElvany K, Welsh M, Markham J, Soebel BE Quantification of regional myocardial blood flow in vivo with $\mathrm{H}_{2}{ }^{15} \mathrm{O}$. Circulation 1984;70:724-733.

23. Parodi $O$, Schelbert $H$, Schwaiger $M$, Hansen $H$, Selin C, Hoffman E. Cardiac emission computed tomography: underestimation of regional tracer concentrations due to wall motion abnormalities. J Comput Assist Tomogr 1984;8:1083-1092. 24. Hoffmann $E$, Huang $S$, Phelps $M$. Quantitation in positron emission computed tomography. I. Effect of object size. J Comput Assist Tomogr 1979;3:299308.

25. Parodi O, Marcassa C, Sambuceti G. What is expected from positron emission tomography in the quantitation of regional myocardial perfusion in man. Bibl Cardiol 1989;4444:101-110.

26. Shah A, Schelbert $H$, Schwaiger $M$, Meuze E, Hansen $H$, Slen $C$, Huang $S$. Measurement of regional myocardial blood flow with ${ }^{13} \mathrm{~N}$ ammonia and PET in intact dogs. J Am Coll Cardiol 1985;5:92-100.

27. Bellina C, Parodi O, Cohnici P, Salvadori P, Toddei L, Fusani L, Guzzardi R, Klosseu G, L'Abbote A, Domata $L$. Simultaneous in vitro and in vivo validation of ${ }^{13} \mathrm{~N}$ ammonia for the assessment of regional myocardial blood flow. $J \mathrm{Nucl} \mathrm{Med}$ 1990;31:1335-1343.

28. Araujo L, Lammertsma A, Rhodes C, McFalls E, Iida H, Rechavia E, Galossi A, DeSilva $R$, Jones $T$, Roseri $A$. Non-invasive quantification of regional myocardial blood flow in normal volunteers and patients with coronary artery disease using ${ }^{15} \mathrm{O}$ labeled CO2 inhalation and PET. Circulation 1990 (in press).

29. Walsh M, Geltman E, Steele R, et al. Augmented myocardial perfusion reserve after coronary angioplasty quantified by positron emission tomography with $\mathrm{H}_{2}{ }^{\mathrm{ts}} \mathrm{O}$. J Am Coll Cardiol 1990;15:119-127.

30. Geltman E, Hennes G, Senneff M, Sobel B, Bergmann S. Increased myocardial perfusion at rest and diminished perfusion reserve in patients with angina and angiographically normal coronary arteries. J Am Coll Cardiol 1990;16: 586-595.

31. McGinn A, Wilson R, Olivari M, Homans $D$, White C. Coronary vasodilator reserve after human orthotopic cardiac transplantation. Circulation 1988;78:12001209.

32. McGinn A, White C, Wilson $R$. Interstudy variability of coronary flow reserve: influence of heart rate, arterial pressure, and ventricular preload. Cinculation 1990;81:1319-1330. 